\title{
Bioavailability of Magnesium Salts - A Review
}

\author{
Ragnar Rylander*
}

\section{BioFact Environmental Health Research Centre, Björkåsv 21, 44391 Lerum, Sweden}

\begin{abstract}
Background: Magnesium supplementation is of value in several different medical disorders. Several kinds of Mg-salts are commercially available.

Purpose: This review evaluates their bioavailability criteria such as solubility, urinary excretion, and plasma levels of magnesium from studies of different Mg-salts.

Conclusion: Although methodology differences were large, the results consistently demonstrate a better bioavailability for Mg-citrate.
\end{abstract}

Keywords: Magnesium, citrate, oxide, bioavailability.

\section{INTRODUCTION}

Magnesium (Mg) is the major cation of the body and is involved in more than 300 enzymes throughout the body. Mg plays a major role for the normal function of muscles, the carbohydrate metabolism, and the skeletal structure [1].

$\mathrm{Mg}$ homeostasis is maintained through intake via food and drinking water. Disturbances appear in cases of insufficient intake or an increased excretion under conditions of acid load [2].

Many studies show that the Mg supply through the diet lies below recommended values, particularly among elderly but also among young females [3, 4]. This implies that $\mathrm{Mg}$ supplementation could be of value for certain groups in the population. Studies over the years have demonstrated that $\mathrm{Mg}$ supplementation may decrease the risk of migraine $[5,6]$, and reduce blood pressure in particular risk groups [7]. Supplementation can also reduce the insulin resistance [8], and the risk of high blood pressure increase during pregnancy [9].

Not all intervention studies with $\mathrm{Mg}$ demonstrate a beneficial effect. This has been taken as evidence that $\mathrm{Mg}$ supplementation is without an effect, often without considering important methodological problems in studies on $\mathrm{Mg}$ supplementation. The absence of an effect may be because the study was made on groups of persons not containing risk individuals. Some studies have used a too narrow range between the basic supply and the supplementation [10]. Another reason could be differences in the bioavailability between different $\mathrm{Mg}$ salts.

*Address correspondence to this author at the BioFact Environmental Health Research Centre, Björkåsv 21, 44391 Lerum, Sweden; Tel: 46708 400101; E-mail: envhealth@biofact.se

ISSN: 2223-3806 / E-ISSN: 1927-5951/14
The purpose of this review is to analyse the information available on the bioavailability of different Mg salts.

\section{METHODOLOGY}

Determination of the bioavailability of $\mathrm{Mg}$ salts is complicated. In contrast to pharmaceutical agents, which represent something alien in the body and can be detected chemically, $\mathrm{Mg}$ is always present in relatively high concentrations. The blood level is in balance with other compartments in the body which can absorb Mg (cells, bone structure). The uptake is through the intestine where about $30 \%$ of the supplied $\mathrm{Mg}$ is absorbed. The $\mathrm{Mg}$ homeostasis is regulated through the secretion and reabsorption in the kidneys, where about $95 \%$ of the excreted, ultrafiltrated $\mathrm{Mg}$ is reabsorbed.

There is today an increasing knowledge regarding the cellular transportation mechanisms for Mg uptake and intra-cellular regulation. The ion channel TRPM6 is of particular importance for the absorption from the intestine and the reabsorption of $\mathrm{Mg}$ secreted into the primary urine [11, 12]. In case of $\mathrm{Mg}$ deficiency, this channel is overexpressed to increase the absorption in the intestine and decrease the excretion with the urine. Taken together this means than the Mg homeostasis is very dependent on a number of different processes, all related to the nutritional characteristics of the individual. The determination of only one or a few of these mechanisms will not give the complete picture of the homeostasis.

Studies on bioavailability can be made by determining the plasma level of $\mathrm{Mg}$ although the range between normal homeostasis and a deficiency is very small. A further complication is that the plasma level of $\mathrm{Mg}$ expresses circadian variation with peak levels 
around 1000 and 2000 hours [13]. This variation, which is around $6 \%$, is present also after supplementation with $\mathrm{Mg}$. Information on the $\mathrm{Mg}$ homeostasis can also be obtained by measuring the urinary excretion over a 24 hour period, although no conclusion can be drawn regarding the total amount of $\mathrm{Mg}$ retained in the body. A total balance could be achieved by measuring the intake as well as the excretion via urine and faeces. Such studies are extremely cumbersome and have not been performed in investigations on bioavailability.

Against this background, a review of a total of eight studies on bioavailability of $\mathrm{Mg}$ salts is presented.

\section{STUDIES}

The bioavailability of Mg-oxide and $\mathrm{Mg}$-citrate was compared in a study with 13 test persons [14]. They received $450 \mathrm{mg} \mathrm{Mg} /$ day and the concentration of $\mathrm{Mg}$ was measured in serum and urine There were no effects on serum-Mg. The urinary excretion increased by $20 \%$ after $\mathrm{Mg}$-oxide and $40 \%$ after $\mathrm{Mg}$-citrate supplementation.

In a study on 16 healthy volunteers, different commercial Mg-preparations were compared [15]. The subjects were asked to abstain from magnesium-rich foods during the study. The different salts were $\mathrm{Mg}$ oxide, -chloride, -lactate, and -aspartate, all in a dose of around $21 \mathrm{mEq}(510 \mathrm{mg})$ per day. The mean urinary excretion of $\mathrm{Mg}$ during control days was around 80 $\mathrm{mg} /$ day. The excretion increased significantly after Mglactate, -aspartate, and -chloride. The fractional absorption was $4 \%$ for Mg-chloride and $9-11 \%$ for the other salts.

In an experimental study the solubility of Mg-oxide and $\mathrm{Mg}$-citrate was evaluated using different concentrations of hydrochloric acid [16]. Mg-oxide was almost non-soluble in water and proportional to the concentration of hydrochloric acid with a solubility of $43 \%$ at $24.2 \mathrm{mEq}$. For Mg-citrate the solubility was $87 \%$ already at $0.72 \mathrm{mEq}$ hydrochloric acid and significantly higher than that of Mg-oxide at all concentrations. 17 subjects received an oral supplementation with $25 \mathrm{mEq}$ (608 mg) Mg-citrate, -oxide, and distilled water after adhering to a Mg standardized diet for three days. In urine collected during 2-4 hours after the load, the amount of magnesium increased by $0.035 \mathrm{mg} / \mathrm{mg}$ creatinine above background levels for Mg-citrate but only by 0.008 after Mg-oxide.

$\mathrm{Mg}$-L-asparate- $\mathrm{HCl}$ as tablets and granules was compared to $\mathrm{Mg}$-oxide in a study on three groups of eight healthy volunteers [17]. The 7-day cumulative urinary excretion of $\mathrm{Mg}$ was measured after a 7-day supplementation with $60 \mathrm{mEq} /$ day $(1450 \mathrm{mg})$ and 90 $\mathrm{mEq} /$ day $(2187 \mathrm{mg})$. The cumulative excretions of $\mathrm{Mg}$ after the Mg-L-aspartate forms at $90 \mathrm{mEq}$ were181 and $187 \mathrm{mg}$ as compared to 137 after Mg-oxide. The same difference was found after $60 \mathrm{mEq}$ although the values were lower.

In a randomized, placebo controlled study 46 healthy subjects were given $300 \mathrm{mg}$ magnesium daily as Mg-citrate, Mg-amino acid chelate or Mg-oxide [18]. Placebo was cellulose or sorbitol. Saliva and blood samples, and 24 hour urine samples were taken at baseline, and 24 hours and 60 days after supplementation. At 60 days the urinary excretion of $\mathrm{Mg}$ was higher after organic $\mathrm{Mg}$ salts than after $\mathrm{Mg}$ oxide. The plasma Mg level at 60 days was higher after $\mathrm{Mg}$-citrate supplementation than after the other forms (0.72 vs 0.69 and $0.65 \mathrm{mmol} / \mathrm{L}$ ).

Magnesium in urine was measured in 18 women after a supply of $\mathrm{Mg}$-lactate/citrate, Mg-lactatehydroxide, Mg-hydroxide, and Mg-chloride with a dose of $15-20.6 \mathrm{mmol}$ (365 and $501 \mathrm{mg}$ ) per day [19]. The excretion in urine 24 hours afterwards was higher than placebo after all supplements with no difference between them although there was a tendency to a higher excretion after Mg-citrate.

In a randomized, double-blind, cross-over study with 41 subjects, Mg-oxide and Mg-citrate were compared [20]. However the dose of Mg-oxide was $520 \mathrm{mg}$ per day and that for Mg-citrate $295.8 \mathrm{mg}$ per day. Because of this large difference in dose, this study does not fulfill the experimental design required for a comparison study. As the different effect variables influenced by the $\mathrm{Mg}$ supplementation were equal for the two salts, this can be taken as an indirect evidence that Mg-citrate (here given at a lower dose) was more efficient than Mg-oxide.

One study with 51 persons investigated the influence of Mg-oxide and Mg-citrate (each $300 \mathrm{mg}$ ) on the intracellular, ionized concentration of magnesium in human leukocytes [21]. The concentration of ionized $\mathrm{Mg}$ was significantly higher after administration of $\mathrm{Mg}$ citrate than $\mathrm{Mg}$-oxide at 9 and 24 hours afterwards.

\section{CONCLUSION}

Concerning methodology there are large differences between the studies. The amounts of $\mathrm{Mg}$ administered span from 296 to $2187 \mathrm{mg} /$ day. To evaluate the effect 
of the administration, Mg was measured in serum, plasma, urine or intracellularly.

In spite of these large methodological variations, the results are quite consistent. The water solubility of a $\mathrm{Mg}$ salt is of importance for the bioavailability. The studies demonstrate that organic salts of $\mathrm{Mg}$ have a higher solubility than inorganic salts. This means that $\mathrm{Mg}$-citrate has a higher absorption than Mg-oxide. This is reflected in the results where the plasma concentration and urinary excretion at different times after administration were higher than for Mg-oxide. In conclusion available data suggest that Mg-citrate is the most appropriate preparation for therapeutic and supplementing purposes.

\section{CONFLICT OF INTEREST}

There is no conflict of interest regarding this review

\section{REFERENCES}

[1] Porr PJ, Nechifor M, Durlach J. Advances in magnesium research. John Libbey Eurotext 2006; pp. 1-206.

[2] Rylander R, Tallheden T, Vormann J. Acid-base conditions regulate calcium and magnesium homeostasis. Magnesium Res 2009; 22: 1-4.

[3] Schimatschek HF, Rempis R. Prevalence of hypomagnesemia in an unseleced German population of 16 '000 individuals. Magnesium Res 2001; 14: 283-90.

[4] Vormann J, Anke M. Dietary magnesium supply, requirements and recommendations - results from duplicate and balance studies in man. J Clin Basic Cardiol 2002; 5: 4953.

[5] Köseoglu Talashoglui A, Grönül S, Kula M. The effects of magnesium prophylaxis in migraine without aura. Magn Res 2008; 21: 101-8.

[6] Peikert A, Wilimzig C, Köhne-Volland R. Prophylaxis of migraine with oral magnesium; results from a prospective, multicentre, placebo-controlled and double blind, randomized study. Cephalgia 1996; 16: 257-63.

http://dx.doi.org/10.1046/j.1468-2982.1996.1604257.x

[7] Rylander R, Arnaud MJ. Mineral water intake reduces blood pressure among subjects with low urinary magnesium and calcium levels. BMC Public Health 2004; 4: 56-61. http://dx.doi.org/10.1186/1471-2458-4-56

[8] Mooren PC, Krüger K, Völker K, Golf SW, Wadepuhl M, Kraus A. Oral magnesium supplementation reduces insulin resistance in non-diabetic subjects - a double-blind, placebocontrolled, randomized trial. Diab Obesity Metabol 2011; 13: 281-84.

http://dx.doi.org/10.1111/j.1463-1326.2010.01332.x
[9]

Bullarbo M, Ödman N, Nestler A, Nielsen Y, Kolisek M, Vormann J, Rylander R. Magnesium supplementation to prevent high blood pressure in pregnancy - a randomised placebo control trial. Arch Obstetr Gynecol 2013; 288: 126974.

http://dx.doi.org/10.1007/s00404-013-2900-2

[10] Sibai BM, Villar MA, Brazy E. Magnesium supplementation during pregnancy: a double-blind randomized controlled clinical trial. Am J Obstetr Gynecol 1989; 161: 115-19. http://dx.doi.org/10.1016/0002-9378(89)90246-9

[11] Quamme GA. Molecular identification of ancient and modern mammalian magnesium transporters. Am J Physiol Cell Physiol 2010; 298: C407-29. http://dx.doi.org/10.1152/ajpcell.00124.2009

[12] Kolisek M, Launay P, Beck A, Sponder G, Serafini N, Brenkus $\mathrm{M}$, et al. SLC41A1 is a novel mammalian $\mathrm{Mg}^{2+}$ carrier. J Biol Chem 2008; 283: 16235-47. http://dx.doi.org/10.1074/jbc.M707276200

[13] Wilimzig C, Latz R, Vierling W, Mutschler E, Trnovec T, Nyulassy $\mathrm{S}$. Increase in magnesium plasma level after orally administered trimagnesium dicitrate. Eur $\mathrm{J}$ Clin Pharmacol 1996; 49: 317-23. http://dx.doi.org/10.1007/BF00226334

[14] Jahnen A, Scharrel $O$, Hesse A. The availability of magnesium compounds from various preparations, In Lasserre $\mathrm{B}$ and Durlach $\mathrm{J}$ (eds) Magnesium - a relevant ion. Libbey 1991; pp. 377-82.

[15] Firoz M, Graber M. Bioavailability of US commercial magnesium preparations. Magnesium Res 2001; 14: 257-62.

[16] Lindberg JS, Zobits MM, Poindexter JR, Pak CY. Magnesium bioavailablity from magnesium citrate and magnesium oxide. J Am Coll Nutr 1990; 9: 48-55. http://dx.doi.org/10.1080/07315724.1990.10720349

[17] Mühlbauer B, Schwenk M, Coram WM, Antonin KH, Etienne $\mathrm{P}$, Bieck PR, Douglas FL. Magnesium-L-aspartate- $\mathrm{HCl}$ and magnesium-oxide: bioavailability in healthy volunteers. Eur $\mathrm{J}$ Clin Pharmacol 1981; 40: 437-38. http://dx.doi.org/10.1007/BF00265863

[18] Walker AF, Marakis G, Christie S, Byng M. Mg citrate found more bioavailable than other $\mathrm{Mg}$ preparations in a randomised, double-blind study. Magnesium Res 2003; 16: 183-91.

[19] Bøhmer T, Røseth A, Holm H, Weberg-Teigen S, Wahl L. Bioavailability of oral magnesium supplementation in female students evaluated from elimination of magnesium in 24-hour urine. Magnesium Trace Elem 1990; 9: 272-78.

[20] Shechter M, Saad T, Shechter A, Koren-Morag N, Silver BB, Matetzky S. Comparison of magnesium status using X-ray dispersion analysis following magnesium oxide and magnesium citrate treatment of healthy subjects. Magnesium Res 2012; 25: 28-39.

[21] Nestler A, Vormann J, Kolisek M. Magnesium supplementation acutely affects intracellular $\mathrm{Mg}^{2+}$ in human leukocytes. FASEB J 2012; 26: Ib278.

\section{DOI: http://dx.doi.org/10.6000/1927-5951.2014.04.01.8}

(C) 2014 Ragnar Rylander; Licensee Lifescience Global.

This is an open access article licensed under the terms of the Creative Commons Attribution Non-Commercial License (http://creativecommons.org/licenses/by-nc/3.0/) which permits unrestricted, non-commercial use, distribution and reproduction in any medium, provided the work is properly cited. 